\title{
Abnormal Cell Count
}

National Cancer Institute

\section{Source}

National Cancer Institute. Abnormal Cell Count. NCI Thesaurus. Code C111124.

The determination of the amount of abnormal cells present in a sample. 